\title{
2008s-13 \\ Claims-Made and Reported \\ Policies and Insurer Profitability in Medical Malpractice
}

\author{
Patricia Born, M. Martin Boyer
}

\begin{tabular}{c}
\hline Série Scientifique \\
Scientific Series
\end{tabular}

Montréal
Mai 2008

(C) 2008 Patricia Born, M. Martin Boyer. Tous droits réservés. All rights reserved. Reproduction partielle permise avec citation du document source, incluant la notice $@$.

Short sections may be quoted without explicit permission, if full credit, including $\odot$ notice, is given to the source.
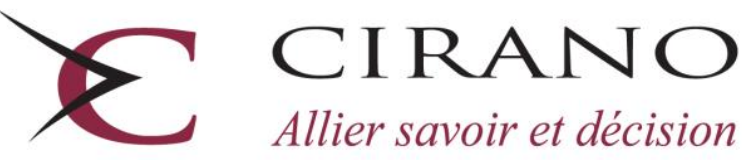

Allier savoir et décision

Centre interuniversitaire de recherche en analyse des organisations 


\section{CIRANO}

Le CIRANO est un organisme sans but lucratif constitué en vertu de la Loi des compagnies du Québec. Le financement de son infrastructure et de ses activités de recherche provient des cotisations de ses organisations-membres, d'une subvention d'infrastructure du Ministère du Développement économique et régional et de la Recherche, de même que des subventions et mandats obtenus par ses équipes de recherche.

CIRANO is a private non-profit organization incorporated under the Québec Companies Act. Its infrastructure and research activities are funded through fees paid by member organizations, an infrastructure grant from the Ministère du Développement économique et régional et de la Recherche, and grants and research mandates obtained by its research teams.

\section{Les partenaires du CIRANO}

Partenaire majeur

Ministère du Développement économique, de l'Innovation et de l'Exportation

\section{Partenaires corporatifs}

Alcan inc.

Banque de développement du Canada

Banque du Canada

Banque Laurentienne du Canada

Banque Nationale du Canada

Banque Royale du Canada

Banque Scotia

Bell Canada

BMO Groupe financier

Bourse de Montréal

Caisse de dépôt et placement du Québec

DMR Conseil

Fédération des caisses Desjardins du Québec

Gaz de France

Gaz Métro

Hydro-Québec

Industrie Canada

Investissements PSP

Ministère des Finances du Québec

Raymond Chabot Grant Thornton

State Street Global Advisors

Transat A.T.

Ville de Montréal

\section{Partenaires universitaires}

École Polytechnique de Montréal

HEC Montréal

McGill University

Université Concordia

Université de Montréal

Université de Sherbrooke

Université du Québec

Université du Québec à Montréal

Université Laval

Le CIRANO collabore avec de nombreux centres et chaires de recherche universitaires dont on peut consulter la liste sur son site web.

Les cahiers de la série scientifique (CS) visent à rendre accessibles des résultats de recherche effectuée au CIRANO afin de susciter échanges et commentaires. Ces cahiers sont écrits dans le style des publications scientifiques. Les idées et les opinions émises sont sous l'unique responsabilité des auteurs et ne représentent pas nécessairement les positions du CIRANO ou de ses partenaires.

This paper presents research carried out at CIRANO and aims at encouraging discussion and comment. The observations and viewpoints expressed are the sole responsibility of the authors. They do not necessarily represent positions of CIRANO or its partners. 


\title{
Claims-Made and Reported Policies and Insurer Profitability in Medical Malpractice
}

\author{
Patricia Born ${ }^{*}$, M. Martin Boyer ${ }^{\dagger}$
}

\begin{abstract}
Résumé / Abstract
La crise de la responsabilité civile des années 70 a mené à la création d'un nouveau type de contrat d'assurance qui avait pour but, selon Doherty (1991), de réduire le risque systématique associé aux polices d'assurance à longue durée. Ces contrats CMR (Claims-Made and Reported) ont obtenu la faveur du public dans les années 80 particulièrement pour ce qui est de l'assurance de la responsabilité civile des professionnels de la médecine. Nous présentons ainsi une étude de la structure et de la performance de l'industrie de l'assurance de la responsabilité civile des professionnels de la médecine en mettant en relief les deux types de contrats dans ce marché. La question à laquelle nous voudrions ultimement répondre est la suivante : pourquoi dans le marché de l'assurance de la responsabilité civile des professionnels de la médecine retrouvons-nous les deux types de contrats alors qu'un seul type est généralement offert dans les autres marchés?
\end{abstract}

Mots clés : assurance de la responsabilité civile des professionnels de la médecine, analyse de la structure et de la performance de l'industrie, contrats CMR.

The liability crisis of the 1970s led to the introduction of a new type of insurance policy designed, according to Doherty (1991), to reduce the un-diversifiable uncertainty associated with writing long-tail liability lines. These new claims-made and reported policies gained favor in place of the traditional occurrence coverage in the early eighties not only in medical malpractice, but also in the general liability arena. Under occurrence coverage, a loss incurred in a given year is covered by the contract for that year, regardless of when the claim is reported. In contrast, a claims-made policy pays only the claims reported in the policy year. Our paper presents a structure, conduct, and performance analysis à la Joskow (1973) of the medical malpractice insurance industry by focusing on the differences between the two contracts. The main question we want to address is why there are two types of contracts that cover the same risk exposure in the medical malpractice insurance industry whereas in other lines of insurance, only one exists primarily.

Keywords: medical malpractice insurance, industry structure and performance analysis, claims-made contracts.

\footnotetext{
* Department of Finance, Real Estate and Insurance, California State University, Northridge, 18111 Nordhoff St., Northridge, CA 91330-8379, patricia.born@ csun.edu.

† M. Martin Boyer, PhD, Département de Finance, HEC Montréal, Université de Montréal, 3000, chemin de la Côte-Ste-Catherine, Montréal, Québec, H3T2A7, martin.boyer@hec.ca.
} 


\section{Introduction}

The medical malpractice insurance industry has been one of the most scrutinized industries in recent years. Periodic performance "crises" - evidenced by increasing premiums and reduced availability of liability coverage - have prompted a variety of legislative responses including, for example, legal reforms and the implementation of state victim compensation funds. Amid ongoing concerns for the rising cost of health care and an increase in the number of uninsured individuals for health care services, it is not surprising that medical malpractice insurers' operations are called to question; to the extent that higher premiums or non-renewal of coverage causes health care providers to reduce or discontinue services, patients' access to care is disrupted. ${ }^{1}$

Attempts to explain problems in the medical malpractice insurance industry typically examine the influence of exogenous factors on the performance of the member insurers. These exogenous factors include increased litigation by patients, increased jury verdicts and out-of-court settlements, falling investment income, rising reinsurance rates, and changes in the legal environment. Interestingly, researchers have devoted little attention to developments within the industry and their potential influence on insurer performance. One such development was the introduction of claims-made policies in place of the traditional occurrence coverage in the mid-1970s. ${ }^{2}$

The traditional insurance contract is occurrence-based, wherein a policyholder is insured for losses that are incurred during the insurance policy year, even if the loss is not reported for many more years. In contrast, a claims-made insurance contract insures policyholders for only those losses that are reported during the policy year even if the loss was incurred many years before (subject to a retrospective date or time limit).

Touted as a way to reduce the uncertainty associated with writing long-tail liability lines (including the uncertain legal environment as in Doherty, 1991), claims-made policies

\footnotetext{
${ }^{1}$ A GAO (2003) report of four states cites mixed evidence that increasing malpractice premiums are related to physician supply.

${ }^{2}$ See Posner (1986) for a discussion of developments and organizational changes in the medical malpractice insurance industry for the period 1970-1985. These developments include the establishment of state-sponsored joint underwriting associations (JUAs) and the formation of physician-owned mutuals, reciprocals, and risk retention groups (RRGs).
} 
gained favor not only in medical malpractice, but also in the general liability arena (Sloan, Bovjberg and Githens, 1991). One major medical malpractice insurer, St. Paul Fire and Marine, switched its entire book of business to claims-made in the 1980s. By 1984, claims-made policies accounted for fifty percent of total premiums written in medical malpractice, and Posner (1986) predicted that "further growth of up to seventy to eighty percent is extremely likely during 1985" (p.45). Yet our data indicate only partial movement by insurers to claims-made policies, and nearly 25 percent of insurers today still write only occurrence based policies.

In our study, we examine firm-level variation in the use of claims-made versus occurrence policies in a national sample of insurers, for the period 1992-2005. We evaluate institutional and organizational factors that might explain why claims-made and occurrence policies coexist in the marketplace. In our analysis, we apply the traditional structure, conduct, and performance paradigm, and focus on the differences between insurers using claims-made policies only, occurrence policies only, or a combination of the two types. In particular, we evaluate the respective roles of organizational form, scale and scope of operations, competition, and profitability, among other factors, in determining the types of policies offered.

The remainder of the paper goes as follows. We next present the theoretical foundations of the emergence of claims-made and reported insurance contract alongside occurrence contracts. In Section 3 we present our structure, conduct, and performance analysis of the line of insurance business where the two types of contracts are present simultaneously, which is the medical malpractice line. We conclude in Section 4 and offer avenues of future research.

\section{Theoretical framework}

Several veins of insurance research have addressed questions pertaining to the unique structure of the U.S. insurance market. The variety of organizational forms, for example, has been linked to incentive conflicts and contracting costs (Mayers and Smith, 1988), capital requirements (Zanjani, 2007), and advantages in addressing problems in adverse selection (Ligon and Thistle, 2005). The insurer's choice of distribution system has been related to contracting problems among policyholders, insurers, and agents (Kim et al., 1996), information asymmetry (Seog, 1999) and impediments to competition (Berger et 
al, 1997). Apparently, we encounter a wide variety of insurers in the market for a wide variety of reasons, despite the fact that certain forms of organization, distribution systems, or both, might suggest efficiency gains over the alternatives.

To say that not much has been written on the economic theory that would explain the existence, in one particular market, of two types of insurance contracts designed to cover the same risk would be an understatement. The only published paper, to our knowledge, that addresses directly the theoretical underpinning of claims-made and reported insurance contracts and the reason for insurers to go from the traditional occurrence contract to the CMR contract is Doherty (1991). He contends that CMR contracts were designed as an answer to liability uncertainty on the market that the insurance industry could not diversify. In his discussion of industry trends, Posner (1986) suggests that insurers switching to claims-made contracts were willing to continue underwriting the risk of patient injuries, but did not want to face the added risk associated with the timing risk (i.e., when the compensation would be paid, given potentially long delays in the legal environment) and the corresponding inflation and investment risks.

Whereas Doherty (1991) approaches the problem from the industry's point of view, the theoretical approach of Boyer and Gobert (2007) looks at the two policies from the policyholder's point of view. They find that CMR policies are preferable to occurrence policies if and only if policyholders discount the future at a higher rate than insurers. In other words, they contend that the only reason why CMR policies exist is that policyholders are more myopic than insurers. The implication of this theory is that, everything else equal, an increase in the discount rate used by insurers (say because of an increase in the interest rate) would induce policyholders to move toward an occurrence policy rather than a CMR policy.

Another possible theory that explains the emergence of the CMR contract from the point of view of the industry is that it helps to retain the policyholder with the industry, if not with the insurer. Because a CMR contract's retroactive date usually goes back only as far as the initial uninterrupted CMR contract was purchased, it becomes very costly for a risk averse policyholder to jump back and forth from being insured, then uninsured, then insured again. Similarly, it is extremely costly to go from a CMR contract to an occurrence contract because one needs to purchase a retroactive occurrence contract 
that covers all previous possible incidents, on top of covering the current ones for all future claims filed.

\section{Empirical Analysis}

Our analysis of the medical malpractice insurance industry by contract type follows the traditional approach in the insurance market structure in that we first present the importance of each type of contract in the U.S. economy as a whole, and the association between the contract type and organizational form.

We then examine several features of market conduct to see if the contract type has any bearing on the array of other insurance products that are offered by insurers, the number of states they operate in, and the sheer size of their operations. Whether the size of the insurer, measured by total assets, is relevant or not in determining the type of contract that is offered is also of interest to us, especially when we examine if size is a significant determinant of the contract type, or the other way around.

Finally, we assess the performance of the two lines of medical malpractice coverage by looking at the loss ratios, expense ratios, and combined ratios for each year in the period under study. Our analysis also focuses on the loss development pattern to see if losses develop differently in one type of contract than the other to assess the difficulty of predicting accurately future losses for the two contract types.

\subsection{The political economy of medical malpractice insurance}

In our assessment of the contract types offered in medical malpractice, we acknowledge that a variety of other factors have influenced that the landscape on which the industry operates. We focus briefly on those factors that have reshaped the market for medical malpractice insurance which may, in turn, relate to contract offerings.

\subsubsection{Medical malpractice crises and underwriting cycles}

The medical malpractice market experiences cycles of hard and soft markets that are

more volatile than those experienced by property-casualty markets in general, presumably because $(\mathrm{GAO}, 2003)$ it takes a long time to resolve malpractice claims and 
the severity of such claims are highly variable. In the past few decades, three dramatic downturns in profitability, and accompanying reports of reduced availability, have been called "crises" by insurance and health policy analysts. Crises beget attention, and with heightened focus on the health care system, the medical malpractice industry became, and continues to be, a prime target for state and federal legislative interest.

\subsubsection{The U.S. Liability System and Tort reform}

Medical malpractice insurers have weathered a variety of changes in their regulatory and legal environments over the past few decades. Most recognized, and consequently the most studied, have been a variety of reforms to the tort environments in which malpractice claims are brought. These reforms, enacted by state legislatures, include caps on noneconomic damages, modifications to joint and several liability, modifications to collateral source rules, caps on punitive damages, limitations on attorney fees, and allowing for periodic award payments. The intent of such reforms is to restore stability in the insurance industry by affecting the number of malpractice claims filed, outcomes of claims filed, or both.

Tort reform measures have been in place in some states for over 30 years ${ }^{3}$, while other states continue to debate whether any reform is needed, or if particular measures, such as caps on noneconomic damages, are consistent with state constitutions. Research on the effects of the reforms consistently show that noneconomic damages caps reduce mean payments in medical malpractice cases (Danzon, 1984; Zuckerman et al., 1990; Yoon, 2001), and improved insurer underwriting performance (Barker, 1992; Born and Viscusi, 1998; and Viscusi and Born, 2005).

\subsubsection{Joint underwriting associations and risk retention groups}

Following the first crisis of availability in the 1970s, forty-three states passed legislation to allow the creation of "residual" markets to provide medical malpractice insurance to high risk medical providers through joint underwriting associations (JUA). Some states never actually created these associations, and at least 15 states terminated their JUA within a few years. Thirteen states had a JUA in active operation in mid-1985, but only 10 were in operation in 1996. Posner (1986) indicates that because many JUA

\footnotetext{
${ }^{3}$ California's Medical Injury Compensation Reform Act was enacted in 1975. The Act continues to serve as a model for state tort reform.
} 
attempted to set a low ceiling on premiums, they may have pushed out the commercial insurers. For whatever reasons, many JUA held a substantial share of the market in their states; the South Carolina JUA had over half of the state market share in 1996, while the Florida JUA had less than one percent (See Appendix A). While all states with JUA require all admitted insurers to participate, some have the additional requirement that these insurers provide a particular form of coverage (i.e., occurrence or claims-made). Unfortunately, we are unable to assess the influence, if any, of JUA in the overall medical malpractice insurance industry; the premiums written through JUA are not included in our analysis at this time.

The federal Liability Risk Retention Act of 1986 encouraged the formation of risk retention groups (RRG) for liability coverage. ${ }^{4}$ The members forming an RRG must be engaged in similar activities, ${ }^{5}$ such that they are exposed to similar risks. There is thus little diversification in the insurer's exposure portfolio since all policyholders are faced with similar risks. One final important risk-bearing limitation of $R R G$ is that their policyholders-owners are not allowed to gain access to state guaranty funds in case of insolvency. The Act basically allowed medical care providers, including physician groups and hospitals, to obtain more control over their insurance programs. This heightened sense of control over losses and premium therefore came at the price of accepting limitations in terms of insurance program scope and in terms of a limited access to the formal and informal capital markets.

The introduction of RRG brings a new type of organization in the market for medical malpractice insurance. They resemble mutual and reciprocal insurance companies in that they are policyholder owned, but they have a very limited scope of operations. In a sense, we may be surprised that RRG would come to exist since they appear to be mutual insurers that are constrained to insurer only one type of risk. What is the advantage of an RRG so that it could coexist with other policyholder-owned insurance companies? There appears to be two such advantages: higher loss control and claims management, and a federal statute rather than individual state statutes.

\footnotetext{
${ }^{4}$ There are ongoing discussions in the United States Congress that would extend risk retention groups to other types of risk, such as property and personal insurance.

${ }^{5}$ Federal Risk Retention Group Statute, 15 U.S.C. § 3902.
} 
It is clear that risk homogeneity should enhance the loss control and claims management abilities of RRG. But this should also be available to mutual and reciprocal insurers that could voluntarily limit the scope of their operations. Although the constraint faced by $R R G$ is more binding than for mutual insurers, it is nevertheless difficult to imagine that it is a sufficient reason to explain the existence of RRG.

A second more probable explanation to the existence of $R R G$ is the fact that they are regulated though a federal statute rather than the states. This federal statute explains why RRG cannot access state guaranty funds in the event of insolvency. And although RRG were typically formed to meet the needs of a local group of providers, once it is licensed, it may enter additional states. As a result many RRG formed in the early 2000 s, decided to be domiciled in Vermont due to the state's particular captive laws, which allow greater flexibility. While regulators generally agree that RRG have helped increase the availability of liability coverage, there are some lingering concerns about the wide variation in state regulatory practices (GAO, 2005).

\subsubsection{The U.S. Health Care Industry}

As the buyers of medical malpractice insurance, the entities supplying health care services play an important role in the determination of the structure, conduct and performance of the insurance industry. For example, the health care industry has seen rapid consolidation, leading to a marked increase in concentration (Gaynor and HaasWilson, 1999). Through consolidation, health care providers become more powerful purchasers of malpractice insurance.

\subsection{Market structure and contract penetration}

\subsubsection{Contract penetration and market growth}

A primary component of any study on the industrial organization of the insurance industry is the focus on the industry structure. We present our assessment of the industry structure with an emphasis on the prevalence of the different types of contracts in the industry. Table 1 below presents the premiums earned in the medical malpractice insurance industry from 1990 through 2005 in total, and as a function of the type of contract that was in force. 
As we can see, total premiums-earned by medical malpractice insurers has more than doubled during the period $1990-2005$. The annual rate of increase is $3.49 \%$ for the occurrence policies and $5.56 \%$ for the CMR policies, with most of the differential increase occurring in the last four years. From 1990 until 2001, the average annual increase in premiums earned was the same for the two types of contracts. From 2001 until 2005 , however, the annual increase in premiums earned was $12.75 \%$ for claimsmade policies whereas it was only $4.70 \%$ for occurrence policies.

\begin{tabular}{|c|c|c|c|c|}
\hline \multicolumn{5}{|c|}{$\begin{array}{l}\text { Table 1. Premium earned (in millions of current dollars) in medical malpractice } \\
\text { insurance by type of contact, } 1990-2005 \text {. }\end{array}$} \\
\hline year & $\begin{array}{l}\text { Total premiums } \\
\quad \text { earned }\end{array}$ & $\begin{array}{l}\text { CMR contract } \\
\text { premiums } \\
\text { earned }\end{array}$ & $\begin{array}{l}\text { OCC contract } \\
\text { premiums } \\
\text { earned }\end{array}$ & $\begin{array}{l}\text { Ratio of CMR to } \\
\text { OCC contract } \\
\text { earned premiums }\end{array}$ \\
\hline 1990 & $4,150,727$ & $2,915,177$ & $1,235,550$ & 2.36 \\
\hline 1991 & $4,041,831$ & $2,863,482$ & $1,178,349$ & 2.43 \\
\hline 1992 & $4,116,903$ & $2,943,184$ & $1,173,719$ & 2.51 \\
\hline 1993 & $4,298,106$ & $3,116,520$ & $1,181,586$ & 2.64 \\
\hline 1994 & $4,722,512$ & $3,315,514$ & $1,406,998$ & 2.36 \\
\hline 1995 & $4,799,522$ & $3,323,055$ & $1,476,467$ & 2.25 \\
\hline 1996 & $4,878,946$ & $3,436,119$ & $1,442,827$ & 2.38 \\
\hline 1997 & $5,032,842$ & $3,591,785$ & $1,441,057$ & 2.49 \\
\hline 1998 & $5,128,893$ & $3,663,239$ & $1,465,654$ & 2.50 \\
\hline 1999 & $5,267,617$ & $3,675,905$ & $1,591,712$ & 2.31 \\
\hline 2000 & $5,351,526$ & $3,490,482$ & $1,861,044$ & 1.88 \\
\hline 2001 & $5,780,544$ & $4,061,636$ & $1,718,908$ & 2.36 \\
\hline 2002 & $9,157,351$ & $6,726,972$ & $2,430,379$ & 2.77 \\
\hline 2003 & $8,302,736$ & $5,806,058$ & $2,496,678$ & 2.33 \\
\hline 2004 & $8,784,556$ & $6,639,518$ & $2,145,038$ & 3.10 \\
\hline 2005 & $8,629,529$ & $6,563,621$ & $2,065,908$ & 3.18 \\
\hline 2006 & $10,140,990$ & $7,785,343$ & $2,355,646$ & 3.30 \\
\hline $\begin{array}{c}\text { Annual increase } \\
1990-2006\end{array}$ & & $7.43 \%$ & $4.83 \%$ & \\
\hline $\begin{array}{c}\text { Annual increase } \\
2001-2006\end{array}$ & & $16.69 \%$ & $5.46 \%$ & \\
\hline
\end{tabular}

This difference in the annual growth rate of each type of contract can also be seen in the fact that the ratio of occurrence total premium to CMR total premium increases during the period. There are two possible explanations to having a higher growth rate of CMR 
premium than occurrence premiums: either more insured are choosing CMR policies over time, or CMR policies are becoming more expensive.

\subsubsection{Ownership structure and contract type}

The ownership structure of insurers that distribute each type of medical malpractice insurance policies is another important component of the organization of the market. Table 2 presents the market share of insurers as a function of their ownership structure (stock company, mutual, reciprocal, risk retention group, or other types of ownership) as well as a function of the type of contract they sell (occurrence only, CMR only, or both) for three specific years: 1992, the first year of our dataset, 1998, the middle year of our dataset and 2005, the last year of out dataset.

\begin{tabular}{|c|c|c|c|}
\hline \multicolumn{4}{|c|}{$\begin{array}{l}\text { Table 2. Market Shares by Ownership Structure, Contract } \\
\text { Type and Selected years (1992, } 1998 \text { and 2006); all insurers }\end{array}$} \\
\hline & 1992 & 1998 & 2006 \\
\hline \multicolumn{4}{|c|}{ Panel A: All Medical Malpractice business } \\
\hline Stock & $58.73 \%$ & $60.74 \%$ & $50.42 \%$ \\
\hline Mutual & $23.63 \%$ & $23.10 \%$ & $28.65 \%$ \\
\hline Reciprocal & $15.87 \%$ & $13.56 \%$ & $14.47 \%$ \\
\hline Risk retention groups & $1.69 \%$ & $1.62 \%$ & $6.17 \%$ \\
\hline Others & $0.07 \%$ & $0.99 \%$ & $0.30 \%$ \\
\hline \multicolumn{4}{|c|}{ Panel B: Claims Made policies } \\
\hline Stock & $58.23 \%$ & $57.65 \%$ & $48.92 \%$ \\
\hline Mutual & $20.37 \%$ & $21.71 \%$ & $28.06 \%$ \\
\hline Reciprocal & $19.06 \%$ & $17.38 \%$ & $15.18 \%$ \\
\hline Risk retention groups & $2.26 \%$ & $2.16 \%$ & $7.46 \%$ \\
\hline Others & $0.08 \%$ & $1.10 \%$ & $0.38 \%$ \\
\hline \multicolumn{4}{|c|}{ Panel C: Occurrence policies } \\
\hline Stock & $59.98 \%$ & $68.45 \%$ & $55.38 \%$ \\
\hline Mutual & $31.81 \%$ & $26.59 \%$ & $30.60 \%$ \\
\hline Reciprocal & $7.89 \%$ & $4.00 \%$ & $12.12 \%$ \\
\hline Risk retention groups & $0.27 \%$ & $0.27 \%$ & $1.88 \%$ \\
\hline Others & $0.04 \%$ & $0.69 \%$ & $0.02 \%$ \\
\hline
\end{tabular}


Panel A of Table 2 presents the market share (measured by earned premiums) by ownership structure for the entire medical malpractice insurance industry. We see that although stock insurers still cater to the majority of the medical malpractice insurance policyholders, their market share in 2005 (50.27\%) is markedly smaller than that in 1992 (58.73\%). Mutual insurers as well as risk retention groups (RRG) filled the gap left by the departure of stock insurers as both types of insurers increased significantly their presence in the market between 1992 and 2005. This is particularly true for RRG whose market share tripled. The rapid reduction in the stock insurers' market share between 1998 and 2005 occurred in both types of contracts as we can see in Panels B and C of Table 2, but not at the same time.

Looking at Panels B and C of the table (CMR only and OCC only), we see that the stock insurers' market share varied differently depending on the type of contract that was sold. Indeed, whereas the market share of stock companies did not vary much in the case of insurers selling CMR insurance contracts between 1992 and 1998, the market share of stock companies increased by almost ten percentage points in the case of insurers selling occurrence insurance policies.

From 1998 until 2005, the market share of stock insurance companies dropped by approximately ten percentage points in the two contract markets. We also see, over these seven years, the rapid emergence of risk retention groups as a popular ownership structure, especially when the insurance contract is claims made. Whereas RRG only occupied $2.26 \%$ of the CMR market in 1992 , they now cater to $8.23 \%$ of the market in 2005.

The story is similar in Table 3 when we examine the number of firms selling medical malpractice insurance rather than their market share. We see an important consolidation of stock insurance companies that were selling occurrence policies as their number plunged from 239 in 1992 to only 151 in 2005. At the same time the number of reciprocal or mutual insurers selling occurrence contracts remained relatively constant with 44 mutual and reciprocals in 1992 and 1998, and 43 in 2005.

The most impressive growth in the number of medical malpractice insurers comes in the form of risk retention groups. Whereas there were only $10 R R G$ in 1992, with 5 writing only CMR contracts (that is 10 RRG in total with only 5 writing OCC contracts), there were 90 RRG in 2005, 69 of which wrote CMR contracts only (that is 90 RRG in total 
with only 21 writing OCC contracts). At the same time, the number of stock insurers writing OCC contracts only declined substantially, going from 101 in 1992 (284 minus 183) to 28 (245 minus 217) in 2005. Over the same period, the number of reciprocals and mutual insurance companies did not vary much.

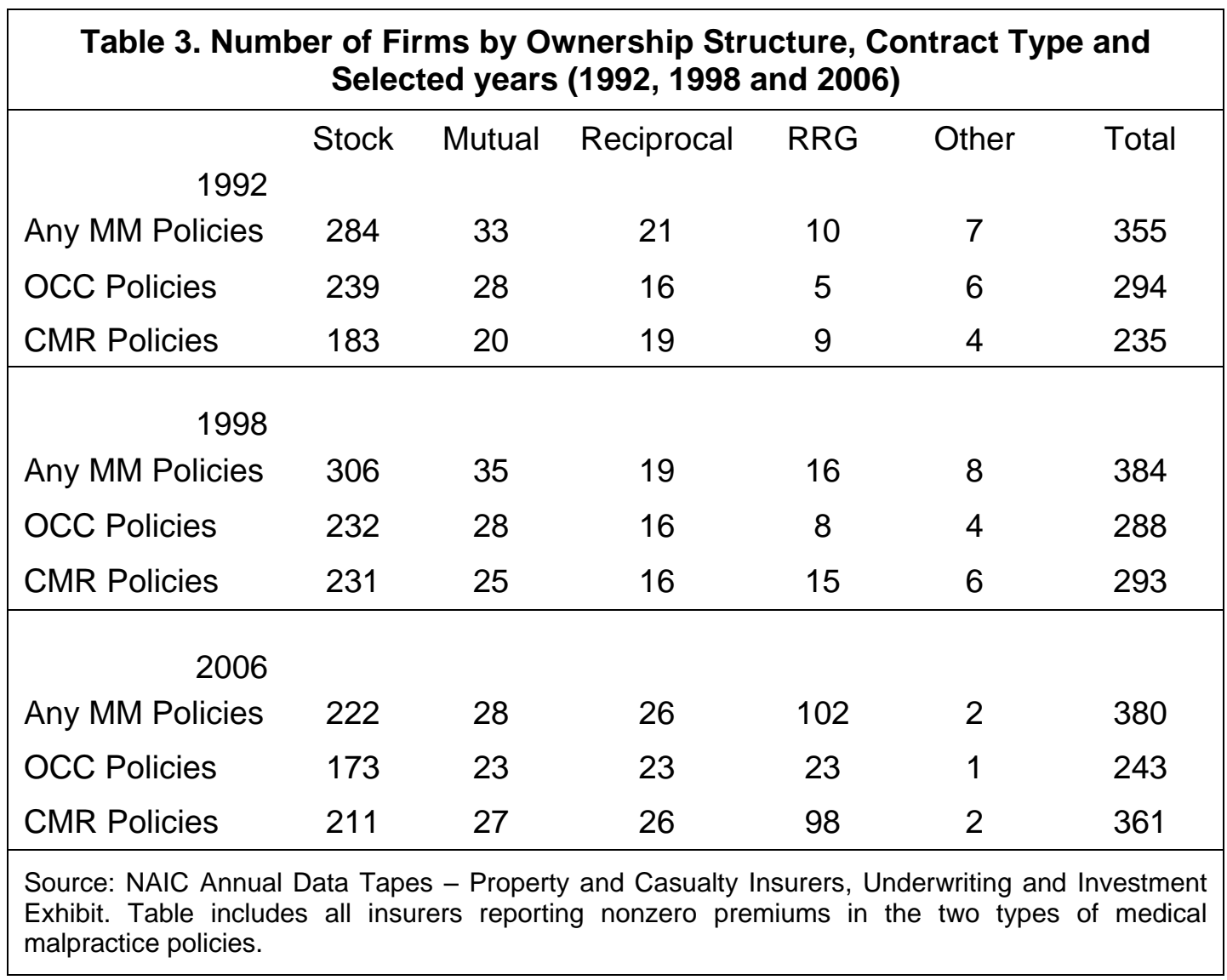

Suppose one were to rank the ownership structure from the form that has more riskbearing ability to the ownership structure that has the least risk-bearing ability, one would clearly list the stock companies as having the highest ability. Because stock insurers can raise extra capital on the market, they are better positioned than any other organizational form to compensate for an unexpected catastrophic loss. What ownership structure would rank the lowest in terms of risk bearing capacity? We would argue that risk retention groups have the lowest ability to absorb a catastrophic loss for two reasons: the absence of an internal capital market and the low diversification of their risk portfolio.

Risk retention groups have little ability to assume a catastrophic loss because a federal statute ${ }^{6}$ prohibits RRGs from insuring personal lines of insurance, such as homeowners

\footnotetext{
${ }^{6}$ Federal Risk Retention Group Statute, 15 U.S.C. § 3902.
} 
and automobile insurance. This reduces an RRG's ability to profit from any economies of scope in providing a full range of insurance services. Furthermore, there is no possibility for policyholders to use their option to access the insurer's other lines surplus (see Phillips et al., 1998) since there is no other line.

In terms of risk diversification, the same Federal statute limits policyholders insured by risk retention groups to be operating in the same line of business, at least in terms of the liability exposure. There is therefore little diversification in the exposure portfolio since all policyholders are exposed to the same risk. Consequently, RRG managers should have the hardest time raising capital following a catastrophic loss because there is no diversification in either the insurance lines not the risk exposure. One final important riskbearing limitation of RRG is that their policyholders-owners are not allowed to gain access to state guaranty funds in case of insolvency. This reduces furthermore the ability of an RRG to gain access to outside funding since the state guaranty fund cannot act as the implicit short end counterparty in a put option transaction.

We saw in Table 3 that risk retention groups are much less likely to sell OCC contracts than any other ownership form of insurer. Indeed, only $23 \%$ of RRG sell OCC contracts, whereas $62 \%$ of stock insurers do. Put another way, $77 \%$ of risk retention groups only offer CMR contracts, a percentage much higher than for any other ownership structure. In terms of market share rather than the number of companies, Table 2 showed that for the three years that we highlighted, the OCC-to-CMR market shares ratio is the highest for stock and mutual insurers and the lowest for RRG and reciprocal insurers.

In terms of capital market access, mutual insurance companies and reciprocals lie between stock companies and risk retention groups. Most researchers assume there is no significant difference between the two forms apart from the fact that mutual insurance companies have a board of directors or trustees through whom business is conducted whereas reciprocals are managed by attorney-in-fact common to all subscribers. An outside creditor is therefore able to come to the rescue of a mutual insurance company by "purchasing" a seat on the board, but it can hardly do so for a reciprocal. As a result, we should rank a mutual insurance company as being slightly more able to access the capital market than a reciprocal insurer. We saw in Table 3 that, similar to risk retention groups, reciprocals are more likely than mutual insurers to sell CMR contracts than OCC contracts. The market shares of these two types of insurance companies in Table 2 tell a similar story. 
The results displayed in Table 2 and Table 3 support Doherty's view that occurrence contracts are inherently riskier for an insurer because changes in the liability award system cannot be diversified. As a result, stock companies are more present in OCC lines than in CMR lines because they can more easily access capital markets to offset important catastrophic losses or changes in the legislation. At the other extreme, risk retention groups have the hardest time gaining access to the capital market. There is thus no surprise to find RRG mainly selling medical malpractice insurance through CMR contracts since it is the type of contract for which the access to the capital market is less important.

\subsubsection{Concentration ratios}

A third aspect of the market structure of medical malpractice insurance between claims made and occurrence lines of business is market concentration. It is well established from basic microeconomic theory that a more concentrated market should provide larger producer surplus. The insurance market is no different so that we should expect more concentrated lines of insurance business associated with greater insurer profitability. ${ }^{7}$ Table 4 presents the top firm market share, the top- 4 firm market share, the top- 8 firm market share and the top-20 firm market share by contract type for 1992, 1998 and 2005.

\begin{tabular}{|c|c|c|c|c|}
\hline \multicolumn{5}{|c|}{$\begin{array}{l}\text { Table 4. Industry Concentration (Premiums Earned Market } \\
\text { Share) by Contract Type, Selected years: 1992, } 1998 \text { and } 2006\end{array}$} \\
\hline & $\begin{array}{l}\text { Top } \\
\text { insurer }\end{array}$ & $\begin{array}{c}\text { Top-4 } \\
\text { insurers }\end{array}$ & $\begin{array}{c}\text { Top- } 8 \\
\text { insurers }\end{array}$ & $\begin{array}{l}\text { Top-20 } \\
\text { insurers }\end{array}$ \\
\hline \multicolumn{5}{|c|}{1992} \\
\hline CMR contracts & 0.16 & 0.29 & 0.43 & 0.64 \\
\hline OCC contracts & 0.14 & 0.43 & 0.61 & 0.82 \\
\hline Overall & 0.12 & 0.28 & 0.39 & 0.61 \\
\hline \multicolumn{5}{|c|}{1998} \\
\hline CMR contracts & 0.10 & 0.25 & 0.38 & 0.62 \\
\hline OCC contracts & 0.18 & 0.45 & 0.59 & 0.80 \\
\hline Overall & 0.08 & 0.24 & 0.38 & 0.62 \\
\hline \multicolumn{5}{|c|}{2006} \\
\hline CMR contracts & 0.06 & 0.20 & 0.25 & 0.55 \\
\hline OCC contracts & 0.16 & 0.44 & 0.60 & 0.82 \\
\hline Overall & 0.07 & 0.20 & 0.33 & 0.56 \\
\hline
\end{tabular}

\footnotetext{
${ }^{7}$ Evidence among lines of insurance is mixed. Bajtelsmit \& Bouzouita (1998) find a significant positive relationship between concentration and profitability among private passenger automobile insurers, while Carroll (1993) finds no significant relationship in the workers compensation market.
} 
For all four concentration measures, the story is basically the same: concentration decreased from 1992 to 2005 for CMR contracts, but it increased for OCC contracts. Overall, combining the two contract types, the top firm and the top-4 firm market share decreased between 1992 and 2005, but the top-8 and top-20 concentration did not move significantly. Looking in particular at the 2005 market shares, we see that the market for CMR policies is a lot less concentrated than the market for occurrence policies. Indeed, for the OCC contract market, the top firm, top-4 firm and top-8 firm market shares is roughly twice as large as in the CMR contract market.

A possible interpretation of why the occurrence market is more concentrated is that insurance companies that were selling only occurrence policies started selling CMR policies, thus eating away at the market shares of established insurers in the CMR market. Another interpretation is that insurers entering the market were providing more CMR contracts than OCC contracts. We examine this interpretation further in the following two tables where we present the number of entrants in the medical malpractice insurance business by contract type (Table 5) as well as the number of firms exiting the market, also by contract type (Table 6).

We see in Table 5 that in the last four years of the data, many more companies are entering the CMR contract line than are entering the OCC contract line. This is true for insurers that are both completely new to the medical malpractice insurance business (166 new CMR insurers since 2002 compared to 69 new OCC insurers) and for insurers that were selling the other type of insurance contract (196 OCC insurers started writing CMR contracts in 2002 and after compared to 99 CMR insurers that started writing OCC contracts during the same period).

This means that, in the past four years, there were twice as many entrants in the CMR line than in the OCC line. Is this difference accounted for by a similar difference in the number of firms exiting each type of medical malpractice insurance market? The following table presents the number of firms exiting by contract type.

We see that for the last four years of the table, insurers who were selling both types of policies were more likely to drop writing OCC contracts while remaining active in CMR policies than the opposite. There were 80 insurers who decided to stop writing occurrence policies from 2001 to 2004 while maintaining their CMR line of business open, whereas only 66 insurers did the opposite. 


\begin{tabular}{|cccccc|}
\hline \multicolumn{5}{|c|}{ Table 5. Entry of firms into medical malpractice lines of business by type of } \\
contract, 1992-2006
\end{tabular}

With respect to insurers who were writing only one of the two lines, 53 insurers exited the occurrence line whereas 34 insurers exiting the CMR line. Overall, over the last four years of the table, the net number of insurers competing in the CMR line increased by 114 firms (363 entries compared to 249 exits) whereas the number of insurers competing in the OCC line decreased by 114 (168 entries and 282 exits). We can thus say that the new entrants were not taking the place of exiting firms as the number of insurers competing in each market went in opposite directions. From 1992 through 2004, the number of insurers in the CMR line increased by 30 companies, whereas the number of insurers in the occurrence line decreased by 179 companies.

Whether it is the concentration ratio or the number of entry net of the number of exits, the implication is similar: we should expect to observe a decrease in the profitability of 
the CMR contract whereas the profitability of the occurrence contracts should have gone up with time. We examine this aspect of the medical malpractice market later in Section 3.3 of the paper.

\begin{tabular}{|c|c|c|c|c|c|}
\hline \multicolumn{6}{|c|}{$\begin{array}{l}\text { Table 6. Number of firms exiting the medical malpractice insurance line of } \\
\text { business by type of contract, } 1990-2004\end{array}$} \\
\hline & \multicolumn{3}{|c|}{ Insurer was writing both types of contracts } & \multicolumn{2}{|c|}{$\begin{array}{l}\text { Insurer was writing only one } \\
\text { type of contract }\end{array}$} \\
\hline year & $\begin{array}{l}\text { Stopped } \\
\text { writing } \\
\text { altogether }\end{array}$ & $\begin{array}{c}\text { Stopped } \\
\text { writing CMR } \\
\text { contracts only }\end{array}$ & $\begin{array}{c}\text { Stopped } \\
\text { writing OCC } \\
\text { contracts only }\end{array}$ & $\begin{array}{c}\text { Stopped } \\
\text { writing CMR } \\
\text { contracts }\end{array}$ & $\begin{array}{c}\text { Stopped } \\
\text { writing OCC } \\
\text { contracts }\end{array}$ \\
\hline 1990 & 11 & 3 & 2 & 3 & 8 \\
\hline 1991 & 20 & 2 & 1 & 0 & 20 \\
\hline 1992 & 13 & 9 & 5 & 3 & 9 \\
\hline 1993 & 16 & 3 & 0 & 3 & 13 \\
\hline 1994 & 16 & 1 & 1 & 4 & 13 \\
\hline 1995 & 24 & 1 & 7 & 13 & 11 \\
\hline 1996 & 25 & 1 & 17 & 2 & 23 \\
\hline 1997 & 21 & 8 & 8 & 5 & 8 \\
\hline 1998 & 44 & 10 & 13 & 9 & 25 \\
\hline 1999 & 69 & 32 & 33 & 32 & 9 \\
\hline 2000 & 18 & 0 & 2 & 11 & 7 \\
\hline 2001 & 41 & 23 & 27 & 12 & 8 \\
\hline 2002 & 20 & 5 & 6 & 9 & 6 \\
\hline 2003 & 62 & 21 & 30 & 8 & 35 \\
\hline 2004 & 8 & 6 & 5 & 3 & 2 \\
\hline
\end{tabular}

\subsection{Market Conduct}

We now turn our focus to the behavior of the firms within the medical malpractice insurance industry. Entry and exit choices, described above in our assessment of the structure of the industry, are just two of many decisions the insurer faces in providing 
malpractice insurance coverage. Here we consider decisions affecting the scale and scope of operations, and the main topic of our research: the choice of contract types offered.

Before going into the general analysis of the scale and scope of medical malpractice insurance companies, it is relevant to see whether insurers concentrate on one particular medical malpractice contract or do they offer both. Table 7 presents the number of insurers, by organizational form, depending on whether they offer only a CMR contract, only an OCC contract or both.

\begin{tabular}{|c|c|c|c|c|c|c|}
\hline 1992 & Stock & Mutual & Reciprocal & RRG & Other & Total \\
\hline Only CMR contracts & 46 & 5 & 5 & 5 & 1 & 62 \\
\hline Only OCC contracts & 102 & 13 & 2 & 1 & 3 & 121 \\
\hline Selling both types & 137 & 15 & 14 & 4 & 3 & 173 \\
\hline Total & 285 & 33 & 21 & 10 & 7 & 356 \\
\hline \multicolumn{7}{|l|}{1998} \\
\hline Only CMR contracts & 75 & 7 & 3 & 8 & 4 & 97 \\
\hline Only OCC contracts & 76 & 10 & 3 & 1 & 2 & 92 \\
\hline Selling both types & 156 & 18 & 13 & 7 & 2 & 196 \\
\hline Total & 307 & 35 & 19 & 16 & 8 & 384 \\
\hline \multicolumn{7}{|l|}{2006} \\
\hline Only CMR contracts & 50 & 5 & 3 & 79 & 1 & 138 \\
\hline Only OCC contracts & 12 & 1 & 0 & 4 & 0 & 17 \\
\hline Selling both types & 161 & 22 & 23 & 19 & 1 & 226 \\
\hline Total & 223 & 28 & 26 & 102 & 2 & 381 \\
\hline
\end{tabular}

The impact of the organizational form on the number of different medical malpractice insurance contracts an insurer offers is striking. In 2005, only $19 \%$ of risk retention groups offered the two contracts compared to half of the stock companies, and $70 \%$ of mutual and reciprocal insurance companies. The fact that risk retention groups are very much concentrated in one particular medical malpractice insurance line is not surprising, 
given the legislation that allowed RRG to exist. What is more surprising is the fact that reciprocals and mutual insurers are more likely to offer the two contracts than stock companies. This may be an indication that reciprocals and mutual insurers are seeking diversification of their risk exposure through the offering of the two contract types.

\subsubsection{Monoline vs. multiline operations}

In the SCP paradigm, a positive relationship between market concentration and profitability is expected because firms have greater opportunities to collude. Several other competing theories suggest that the relationship between market structure and performance stems from other characteristics, including revenue x-efficiencies, and scale efficiencies. ${ }^{8}$ Revenue $x$-efficiencies result from diversification across product lines, where such diversification is driven by market imperfections, such as information opacity. Berger (2000) notes that risk diversification by financial services firms may increase revenue efficiency because it improves their offering of outputs of risk-pooling and riskbearing.

Table 8 presents an indication of insurers' focus on the medical malpractice lines versus other lines of property-liability insurance. Insurers that provide OCC contracts exclusively tend to be much less focused on medical malpractice insurance in general. Among these insurers, the share of underwriting operations devoted to medical malpractice doubled over our sample period, from 9.1 percent to 17.3 percent, with a large increase occurring between 2001 and 2002, when the number of firms offering OCC contracts declined from 60 to 37 .

In contrast, the firms that write only CMR contracts are generally more focused on the medical malpractice line. Through our sample period, CMR business represents 30-50 percent of these insurers' business. Even when the RRGs are excluded from this sample, the share of business in the CMR line ranges from 25-46 percent of the insurers' property-liability business. This is significantly higher than the proportion of medical malpractice insurance in an occurrence-focused insurer's entire book of business.

\footnotetext{
${ }^{8}$ For further discussion of these characteristics as they pertain to the property-liability insurance industry, see Choi and Weiss (2005).
} 


\begin{tabular}{|c|c|c|c|c|c|}
\hline \multicolumn{6}{|c|}{$\begin{array}{l}\text { Table 8. Average share of total } P / L \text { business in Medical Malpractice* } \\
\text { (selected years) }\end{array}$} \\
\hline & 1992 & 1998 & 2001 & 2002 & 2006 \\
\hline \multicolumn{6}{|l|}{ Including RRGs } \\
\hline Writes OCC only & 0.091 & 0.090 & 0.077 & 0.151 & 0.252 \\
\hline Writes CMR only & 0.503 & 0.310 & 0.330 & 0.439 & 0.727 \\
\hline Writes both & 0.347 & 0.383 & 0.328 & 0.355 & 0.433 \\
\hline \multicolumn{6}{|l|}{ Excluding RRGs } \\
\hline Writes OCC only & 0.082 & 0.080 & 0.065 & 0.049 & 0.095 \\
\hline Writes CMR only & 0.450 & 0.246 & 0.244 & 0.277 & 0.409 \\
\hline Writes both & 0.329 & 0.359 & 0.299 & 0.322 & 0.383 \\
\hline \multicolumn{6}{|c|}{$\begin{array}{l}\text { Source: NAIC Annual Data Tapes - Property and Casualty Insurers, Underwriting and } \\
\text { Investment Exhibit, Part } 1 \text {. Share defined as total medical malpractice premiums written / total } \\
\text { premiums written. "The difference between average shares form "writes OCC only" and "writes } \\
\text { CM only" is significant for all years shown (based on 2-sample t-test, } 99 \% \text { confidence level). }\end{array}$} \\
\hline
\end{tabular}

Table 9 provides another indication of the extent to which insurers in the market are focused on medical malpractice versus other property-liability business. Here we show the number of firms that write medical malpractice exclusively. The number of firms that write only medical malpractice insurance has increased over our sample period, largely due to the entry of RRGs in the latter half of the period. More firms are writing CMR contracts only, and fewer firms are writing only OCC contracts. When we look at the total number of insurers that wrote medical malpractice insurance, (356 in 1992, 384 in 1998 and 398 in 2005) we see that medical malpractice insurance is becoming a much more specialized line in 2005 than in the first half of the sample as almost a quarter of all insurers in 2005 are only exposed to medical malpractice liability risk. Compared to a rate of $12 \%$ in 1992 and of $9 \%$ in 1998 , the rate of $24 \%$ in 2005 is a clear outlier. This increase in the specialization of the medical malpractice insurance business is mainly due to the advent of risk retention groups, but not only so.

The number of non-RRG insurers that write no other insurance than medical malpractice is much higher in 2005, when there are 42 non-RRG monoline medical malpractice insurers, than in 1998, when there were only 26 . In comparison, there were 351 multi- 
line insurers that wrote medical malpractice insurance in 1998 and 304 in 2005 . The ratio of non-RRG monoline insurers to multi-line insurers is twice as high in 2005 than in 1998 (14\% versus 7\%). The results in the previous two tables provide further support of Doherty's view that OCC contracts are inherently riskier for an insurer, and since the changes in the liability award system cannot be diversified, insurers that offer OCC contracts must seek other means for diversifying, i.e., by writing other lines of coverage.

\begin{tabular}{|c|c|c|c|}
\hline \multicolumn{4}{|c|}{ Others } \\
\hline OCC only & 1 & 17 & 18 \\
\hline CMR only & 4 & 14 & 18 \\
\hline Writes both & 3 & 38 & 41 \\
\hline Total & 8 & 69 & 77 \\
\hline \multicolumn{4}{|c|}{1998} \\
\hline OCC only & 0 & 16 & 16 \\
\hline CMR only & 3 & 13 & 16 \\
\hline Writes both & 4 & 20 & 24 \\
\hline Total & 7 & 49 & 56 \\
\hline \multicolumn{4}{|c|}{2006} \\
\hline OCC only & 2 & 1 & 3 \\
\hline CMR only & 49 & 16 & 65 \\
\hline Writes both & 15 & 31 & 46 \\
\hline Total & 66 & 48 & 114 \\
\hline
\end{tabular}

\subsubsection{Single vs. multiple state operations}

The scale efficiency hypothesis implies that firms operating at an optimal scale achieve lower costs and higher profits. We evaluated whether the scale of operations is related to the types of contracts offered by medical malpractice insurers, first by assessing the extent to which insurers are geographically diversified. Table 10 provides a breakdown of insurers by the number of states in which they sell OCC and CMR policies. 


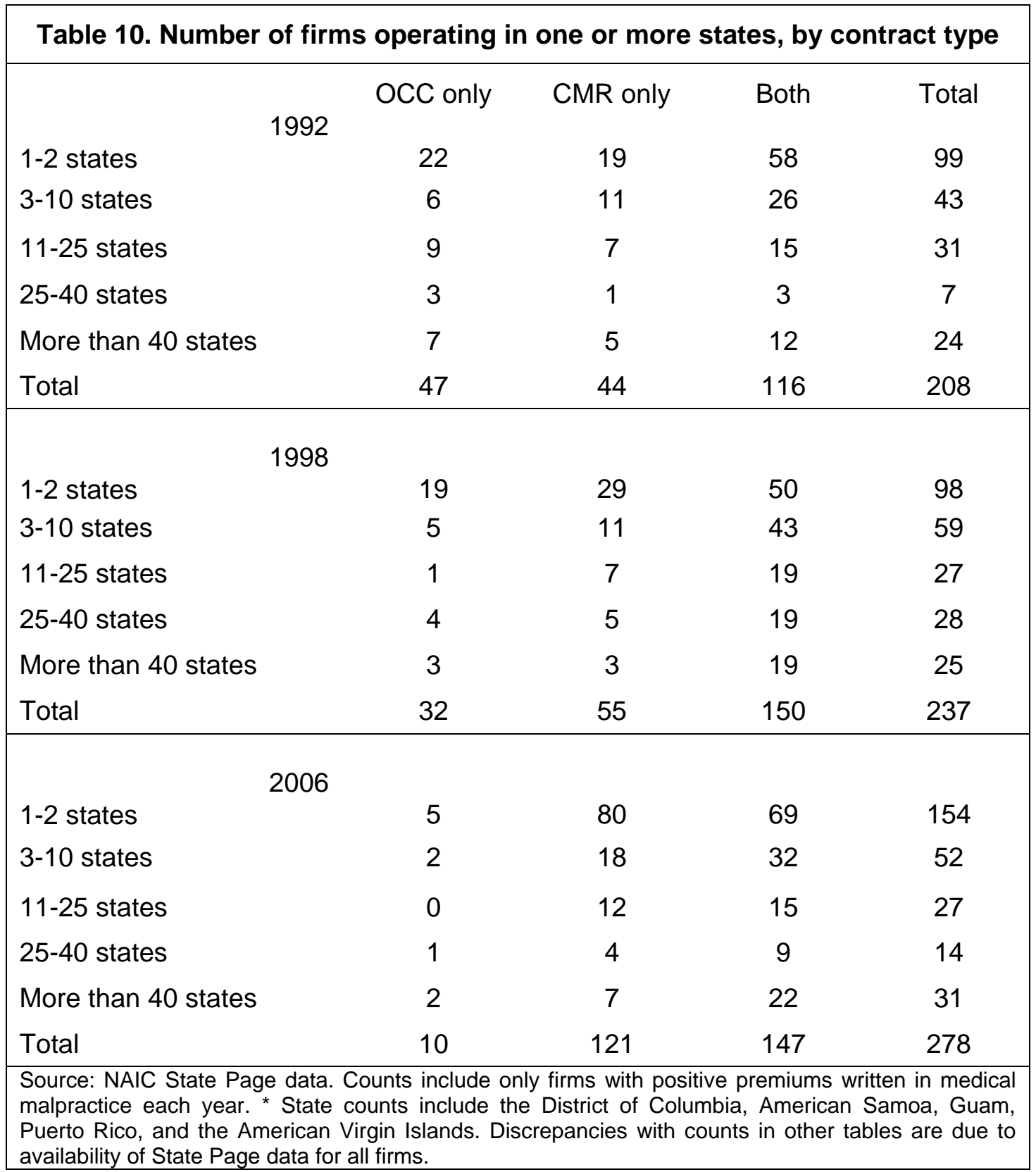

With the advent of risk retention groups, we see that insurers that are selling occurrence policies only no longer were able to compete in single states. As a result insurers interested in providing occurrence coverage to their policyholders had to diversify their risk geographically by selling policies in more states. Whereas less than $10 \%$ of insurers were selling OCC policies only in 50 states or more in 1992 and 1998, 56\% do so in 2005. The same geographic diversification trend is also observable for insurers selling CMR contracts only and for insurers selling both contract types. 
Risk retention groups (RRGs) must be licensed in at least one state, but the federal Liability Risk Retention Act of 1986 allows them to underwrite risks in other states once licensed. Interestingly, more than half of the RRGs providing coverage in 2005 were operating in 3 or more states, as we can see in Table 11. Only four RRGs operated in only one state, and these offered only claims made coverage.

\begin{tabular}{|c|c|c|c|c|}
\hline \multicolumn{5}{|c|}{ Table 11. Concentration of Risk Retention Groups, 2006} \\
\hline & $\begin{array}{c}\text { OCC } \\
\text { policies only }\end{array}$ & $\begin{array}{c}\text { CMR } \\
\text { policies only }\end{array}$ & Both & Total \\
\hline 1-2 states & 3 & 55 & 12 & 70 \\
\hline 3-10 states & 1 & 12 & 1 & 14 \\
\hline $11-25$ states & 0 & 10 & 1 & 11 \\
\hline $25-40$ states & 0 & 1 & 2 & 3 \\
\hline More than 40 states & 0 & 1 & 3 & 4 \\
\hline Total & 4 & 79 & 19 & 102 \\
\hline
\end{tabular}

\subsection{Performance}

Joskow (1973) writes "the notion of industry performance is of course quite ambiguous, primarily because of its multidimensional nature" (p.398). This statement is as true then as it is now. We will nonetheless examine the performance of the medical malpractice insurance industry depending on the type of contract that is offered. This analysis will be conducted in terms of underwriting performance of each contract through the use of the insurers' loss ratio, and the expenses associated with these two contracts through the use of the insurers' expense and combined ratios.

Following Joskow (1973), traditional papers on the structure, performance and control of property and casualty insurance companies have usually included a section on the insurers' distribution system and on supply shortages. The NAIC data does not offer us any information regarding the distribution channel of medical malpractice insurance products, unfortunately. It is therefore impossible to examine with this dataset whether CMR contracts are more easily distributed through direct writers or independent agents. 
In terms of supply of medical malpractice insurance, we discussed earlier in the paper three consequences of supply shortages. The first one is that the medical malpractice insurance market experiences hard and soft markets that are extremely volatile, which reduces the policyholder's ability to smooth his income over time. This is presumed to be the result of the particularly long time it takes to resolve malpractice claims and the large variation in the severity of such claims. A second consequence of supply shortages is that state and federal legislatures investigates and eventually reformed the medical malpractice insurance market through caps on noneconomic damages. Also, forty-three states passed legislation to allow the creation of joint underwriting associations. Although some were never created and others were terminated within a few years, 10 joint underwriting associations were in still operation in 1996 (see the Appendix). Finally, a third consequence of supply shortages in the medical malpractice insurance market is the enactment of the Liability Risk Retention Act of 1986 by the federal government, which encouraged the formation of a new ownership structure in the medical malpractice insurance industry: Risk retention groups. This Act allowed physician groups and hospitals to obtain more control over their insurance programs. Regulated though a federal statute, risk retention groups were typically formed to meet the needs of a local group of providers although in time they entered many states.

\subsubsection{Underwriting Performance}

An interesting comparison we can make between the two contracts is with respect to the evolution of the insurers' loss ratios, as displayed in Table 12. As we can see from 1995 on, the median loss ratio for OCC policies is consistently lower than the loss ratio for CMR policies.

Prior to 1995 CMR lines were more profitable than OCC lines in four of the five first years of our data, the only odd-year out is 1991. Since 1995, the loss ratios of the two lines are highly positively correlated with each other $(\rho=0.82)$. Strangely, prior to 1995 the correlation between the two lines' loss ratios is half of that.

In the previous sections of the paper, we hypothesized that since the concentration ratio in the CMR line was going down at the same time as the number of insurers was going up, we should observe a decrease in the line's profitability, at least compared to the OCC line where the concentration of companies was increasing and the number of companies was decreasing. Even though the profitability trend is statistically different in 
the two lines, both are increasing with time. Moreover, the statistical difference exists only because of the period prior to 1995. After that year, there is no statistically significant difference in the trend parameter for each line's median loss ratio, which suggests that the number of entries and exists and the level of concentration did not have much impact on the two lines' profitability.

\begin{tabular}{|c|c|c|c|c|}
\hline \multicolumn{5}{|c|}{$\begin{array}{l}\text { Table 12. Median loss ratio (losses incurred divided by premiums } \\
\text { earned) in medical malpractice insurance by type of contact, 1990-2006 }\end{array}$} \\
\hline Year & $\begin{array}{l}\text { CMR loss } \\
\text { ratio }\end{array}$ & $\begin{array}{l}\text { OCC loss } \\
\text { ratio }\end{array}$ & $\begin{array}{l}\text { Medical } \\
\text { malpractice } \\
\text { loss ratio }\end{array}$ & $\begin{array}{c}\text { CMR loss ratio } \\
\text { versus } \\
\text { OCC loss ratio * }\end{array}$ \\
\hline 1990 & 0.718 & 0.828 & 0.719 & Yes \\
\hline 1991 & 0.914 & 0.768 & 0.778 & Yes \\
\hline 1992 & 0.877 & 1.000 & 0.880 & Yes \\
\hline 1993 & 0.795 & 0.880 & 0.840 & No \\
\hline 1994 & 0.708 & 0.749 & 0.666 & No \\
\hline 1995 & 0.778 & 0.706 & 0.717 & No \\
\hline 1996 & 0.873 & 0.707 & 0.798 & Yes \\
\hline 1997 & 0.770 & 0.732 & 0.731 & No \\
\hline 1998 & 0.775 & 0.700 & 0.737 & Yes \\
\hline 1999 & 0.890 & 0.795 & 0.857 & Yes \\
\hline 2000 & 0.882 & 0.804 & 0.848 & Yes \\
\hline 2001 & 0.874 & 0.808 & 0.854 & Yes \\
\hline 2002 & 0.723 & 0.678 & 0.682 & Yes \\
\hline 2003 & 0.754 & 0.632 & 0.725 & Yes \\
\hline 2004 & 0.695 & 0.671 & 0.684 & Yes \\
\hline 2005 & 0.692 & 0.553 & 0.684 & Yes \\
\hline 2006 & 0.666 & 0.591 & 0.681 & Yes \\
\hline $\begin{array}{c}\text { Average } \\
(1990-2006)\end{array}$ & 0.787 & 0.741 & 0.758 & Yes \\
\hline $\begin{array}{c}\text { Average } \\
(1995-2006)\end{array}$ & 0.781 & 0.698 & 0.750 & Yes \\
\hline \multicolumn{5}{|c|}{$\begin{array}{l}\text { Source: NAIC Annual Data Tapes - Property and Casualty Insurers, Underwriting and } \\
\text { Investment Exhibits and Schedule P, Part } 2 \mathrm{~F} \text {. Table includes only insurers with positive } \\
\text { premiums earned in each year. Losses incurred include defense and cost containment } \\
\text { expenses. *Significance of differences between medians was determined through quantile } \\
\text { regression with bootstrapped standard errors. Significance of differences between averages } \\
\text { was determined using a Two-Sample t-Test. }\end{array}$} \\
\hline
\end{tabular}


In light of the fact that more and more premiums are earned in the CMR line than the OCC line, one should be puzzled by why insurance companies are flocking toward the contract that has the lowest median profitability over the past ten years. We see three possible explanations for this result.

\subsubsection{Expenses}

It could be that the expenses associated with managing an occurrence book of business are greater than the expenses associated with the CMR contract. This is a likely explanation, but unfortunately unverifiable for the entire industry since expenses are generally not allocated by line of business.

By focusing only on a subset of companies that mostly (or only) sold medical malpractice insurance (i.e., insurers that have more than $75 \%$ of their total premium written in medical malpractice insurance) we are able to assess the expenses associated with offering each type of insurance contract. Doing this exercise suggests that the expense ratio (other underwriting expenses divided by total premiums written) is generally greater for OCC policies than for CMR policies, as we see in Table 13. Except for the years 2001, 2002 and 2005, the median expense ratio for insurers writing only OCC contracts was higher than the ratio for insurers writing only CMR contracts.

Another interesting result in the table is that insurers who were selling both types of policies had an expense ratio that was significantly smaller than firms that were selling only one type of contract (except in the last year of the data). Although this may only be a further indication that there are economies of size and scope in the medical malpractice insurance industry, it is still puzzling why insurers would only offer one type of contract if they can significantly reduce their expense ratio by offering both types of contract.

We obtain a different view of profitability when we compute the combined ratio (median loss ratio plus median expense ratio). Figure 1 confirms that the OCC contract remains more profitable on average, but its dominance over the CMR contract is not as pronounced as when we compared the contract-specific loss ratios. It is also interesting to note that since 2001, the combined ratio in medical malpractice insurance is lower than 1 for both categories of firms. 
Table 13. Median expense ratios (other underwriting expenses divided by total premiums written) in medical malpractice insurance by type of contact, 1992-2006.

\begin{tabular}{|c|c|c|c|c|}
\hline Year & $\begin{array}{l}\text { Firms writing } \\
\text { only CMR } \\
\text { policies } \\
\end{array}$ & $\begin{array}{l}\text { Firms writing } \\
\text { only OCC } \\
\text { policies }\end{array}$ & $\begin{array}{c}\text { Firms writing } \\
\text { both types of } \\
\text { policies }\end{array}$ & $\begin{array}{c}\text { CMR expense ratio } \\
\text { versus } \\
\text { OCC expense ratio * }\end{array}$ \\
\hline 1992 & 0.205 & 0.333 & 0.167 & Yes \\
\hline 1993 & 0.252 & 0.288 & 0.164 & Yes \\
\hline 1994 & 0.256 & 0.331 & 0.208 & No \\
\hline 1995 & 0.265 & 0.323 & 0.226 & Yes \\
\hline 1996 & 0.242 & 0.280 & 0.196 & No \\
\hline 1997 & 0.295 & 0.337 & 0.198 & No \\
\hline 1998 & 0.294 & 0.321 & 0.204 & Yes \\
\hline 1999 & 0.240 & 0.328 & 0.225 & Yes \\
\hline 2000 & 0.274 & 0.295 & 0.198 & Yes \\
\hline 2001 & 0.263 & 0.257 & 0.230 & No \\
\hline 2002 & 0.242 & 0.223 & 0.192 & No \\
\hline 2003 & 0.218 & 0.309 & 0.171 & Yes \\
\hline 2004 & 0.243 & 0.258 & 0.172 & No \\
\hline 2005 & 0.276 & 0.200 & 0.208 & No \\
\hline 2006 & 0.244 & 0.406 & 0.196 & Yes \\
\hline $\begin{array}{c}\text { Average } \\
\text { (1992-2006) }\end{array}$ & 0.254 & 0.299 & 0.197 & Yes \\
\hline
\end{tabular}

Source: NAIC Annual Data Tapes - Property and Casualty Insurers, Underwriting and Investment Exhibits. Subset of the data for insurance companies that mostly (or only) wrote medical malpractice insurance (more than $75 \%$ of their book of business). ${ }^{*}$ Significance of differences between medians was determined through quantile regression with bootstrapped standard errors. Significance of differences between averages was determined using a Two-Sample t-Test.

Another possibility is that CMR policies dominate OCC policies for long tail lines, for other reasons than insurer expenses. The theory developed by Doherty (1991) suggests that occurrence contracts are riskier than CMR contracts for insurers because of the systematic risk component associated with court awards. If that is the case, one should indeed expect occurrence contracts to generate higher profits at regular intervals until a catastrophic event (i.e., an unexpected generous court award that makes jurisprudence or a new court decision as to the definition of risk) occurs. It is then possible that the medical malpractice insurance market has not suffered such an unexpected shock to the liability side of its balance sheet. 


\section{Figure 1: Combined Ratios, 1992-2006}

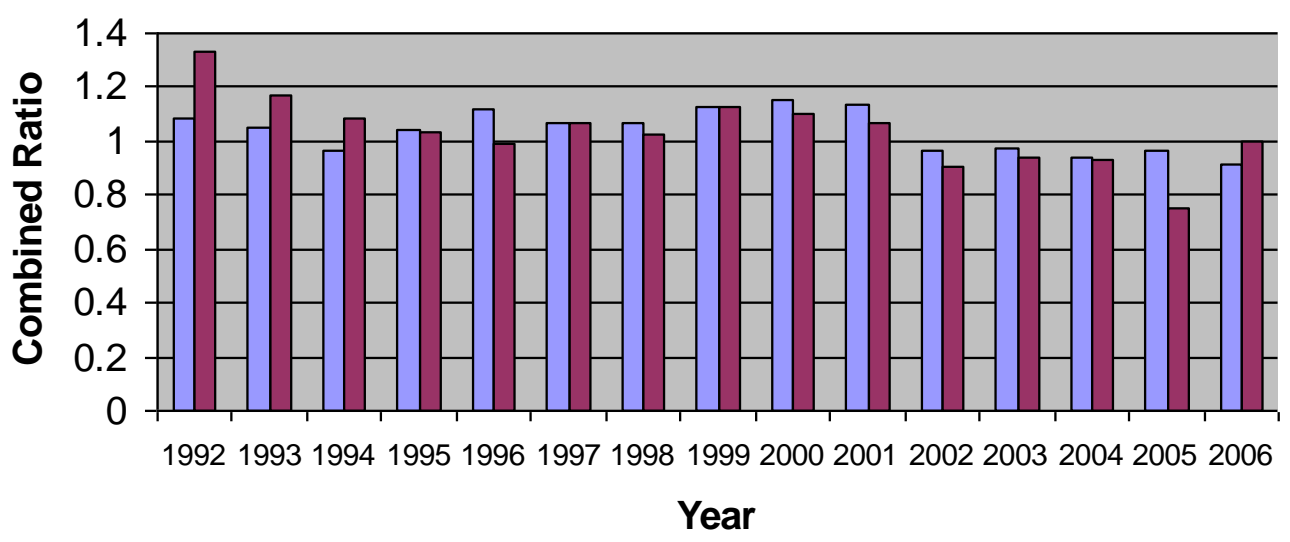

$\square$ Firms writing only CMR $\square$ Firms writing only OCC

\subsubsection{Loss ratio of new entrants}

Earlier, we showed that entrants to the market over this period were more likely to provide claims-made coverage than occurrence contracts. To better understand this trend, we examine the evolution of the loss ratios for the new entrants in the medical malpractice insurance market. An examination of this evolution by contract type should tell us if there are any short-term profits to be made in the claims-made markets; we expect that these profits disappear in the long run. Table 14 presents the reported loss ratios for each year after an insurer enters the particular type of contract.

Selecting only the new entrants in the market, we see that firms that initially enter the CMR insurance contract market only have a much better loss ratio than the new entrants in the OCC contract market only. The clear domination of the CMR line in the short run does not translate into the long run as the CMR loss ratio overtakes the OCC loss ratio by the fifth year, and remains worse thereafter. In the first six years of entering the medical malpractice insurance industry, the average loss ratio for insurers selling OCC contracts only remains approximately the same. This contrasts with the loss ratio of insurers selling CMR contracts that increases on average by almost $50 \%$ over the same six initial years of existence. Assuming that earned premiums remain the same over these eight years in the two lines (which means that incurred losses remain the same every year for the occurrence line), the two lines are as profitable if losses incurred in the CMR contracts increase on average by $10 \%$ per year. 


\begin{tabular}{|c|c|c|c|c|}
\hline \multicolumn{5}{|c|}{ Table 14. Median reported loss ratios for new entrants from entrance through } \\
eight years in the market, by contract type \\
\hline $\begin{array}{c}\text { Years writing } \\
\text { contract type: }\end{array}$ & $\begin{array}{l}\text { Writing CMR } \\
\text { contract only }\end{array}$ & $\begin{array}{l}\text { Writing OCC } \\
\text { contract only }\end{array}$ & $\begin{array}{c}\text { Writing both } \\
\text { contracts }\end{array}$ & $\begin{array}{c}\text { CMR loss ratio } \\
\text { versus } \\
\text { OCC loss ratio * }\end{array}$ \\
\hline 1 (initial year) & 0.566 & 0.710 & 0.660 & No \\
\hline 2 & 0.681 & 0.690 & 0.684 & No \\
\hline 3 & 0.727 & 0.750 & 0.726 & No \\
\hline 4 & 0.752 & 0.760 & 0.783 & No \\
\hline 5 & 0.730 & 0.703 & 0.750 & Yes \\
\hline 6 & 0.815 & 0.695 & 0.763 & Yes \\
\hline 7 & 0.817 & 0.681 & 0.774 & Yes \\
\hline 8 (fully developed) & 0.815 & 0.730 & 0.768 & No \\
\hline $\begin{array}{l}\text { Source: NAIC Annual Data Tapes - Property and Casualty Insurers, Underwriting and Investment } \\
\text { Exhibits and Schedule P, Part 2F. * Significance determined through quantile regression with } \\
\text { bootstrapped standard errors. }\end{array}$ \\
\hline
\end{tabular}

The results of our analysis of loss ratios and expenses do not suggest an obvious advantage, in the long run, for an insurer to write one particular form of contract. We recognize, however, that the reported loss ratio may be a bad measure of insurer profitability in the case of long tail lines of business. A more accurate measure of profitability should take the loss development into account. For example, if insurers systematically under-estimate incurred losses for occurrence policies, using the reported loss ratio would over-estimate the profitability of the occurrence policy line of business. We address this loss development concern next.

\subsection{Loss development}

Loss development is an important part of the financial operations of insurance companies, especially in the case of long tail lines. Systematic over-estimation or underestimation of incurred losses can cause the insurer problems either from government, who is losing tax revenues, or from insurance regulators, who find reserves to be insufficient to cover future losses. A recent study by Grace and Leverty (2007), using loss development "error" measures suggested by Weiss (1985) and Kazenski, Feldhaus, and Schnieder (1992) finds that firms with a greater percentage of premiums written in a price regulated environment are more likely to over-reserve. We therefore feel that 
comparing the loss development pattern of occurrence policies with the loss development pattern of CMR policies can tell us a lot about the usefulness of one contract over the other.

\subsubsection{Loss development patterns}

When insurers report losses incurred for a given policy year, they have limited information on the actual losses that will ultimately be associated with the policies written that year. The figure reported is an estimate that reflects the claims already paid, the insurer's own past experience in loss development, anticipated inflation and interest rates, and anticipated changes in the legal and regulatory environment. Misestimation, which is measured by comparing the reported losses to those restated in subsequent years, results from unanticipated changes in these variables. ${ }^{9}$

We are interested in whether misestimation is more or less likely among insurers writing CMR contracts when compared to those writing OCC contracts. To the extent that insurers writing either type of policy have information about losses incurred and reported within the policy period, loss development for both policy types would reveal adjustments solely due to unanticipated inflation and interest rates. We suspect, however, that the misestimation associated with CMR contracts is lower than that associated with OCC contracts. By design, loss estimates on CMR contracts should result in little or no incurred but not reported losses, since the coverage is limited to losses actually reported in the policy period. In contrast, OCC contracts may have a significant share of losses that have been incurred, but have not been reported - possibly because the loss is not even determined yet. For CMR contracts, the uncertainty with regard to the effects of changes in the legal and regulatory environments is practically eliminated. This follows from Doherty's (1991) suggestion that CMR contracts were designed as an answer to liability uncertainty.

Figure 2 shows the loss development patterns for CMR and OCC policies for three policy years: 1990, 1994 and 1998. For each of these three years, the figure shows the median value of the firm-level reported loss ratio in each contract type, and the

\footnotetext{
${ }^{9}$ Several studies (e.g., Petroni, Ryan and Wahlen, 2000) have suggested reasons why insurers might manipulate reported losses, including avoidance of regulatory scrutiny, but Grace and Leverty (2006) suggest that most reserving errors result from true errors, not from manipulation.
} 
subsequent developed loss ratios (developed losses divided by earned premiums). The initially reported loss ratio for OCC policies is higher than that reported for CMR policies in 1990 and 1994, and basically equal to that reported for CMR policies in 1998. Interestingly, the two types of policies do not necessarily develop in the same way suggesting a role for factors other than unanticipated interest rates.

Figure 2: Loss Development

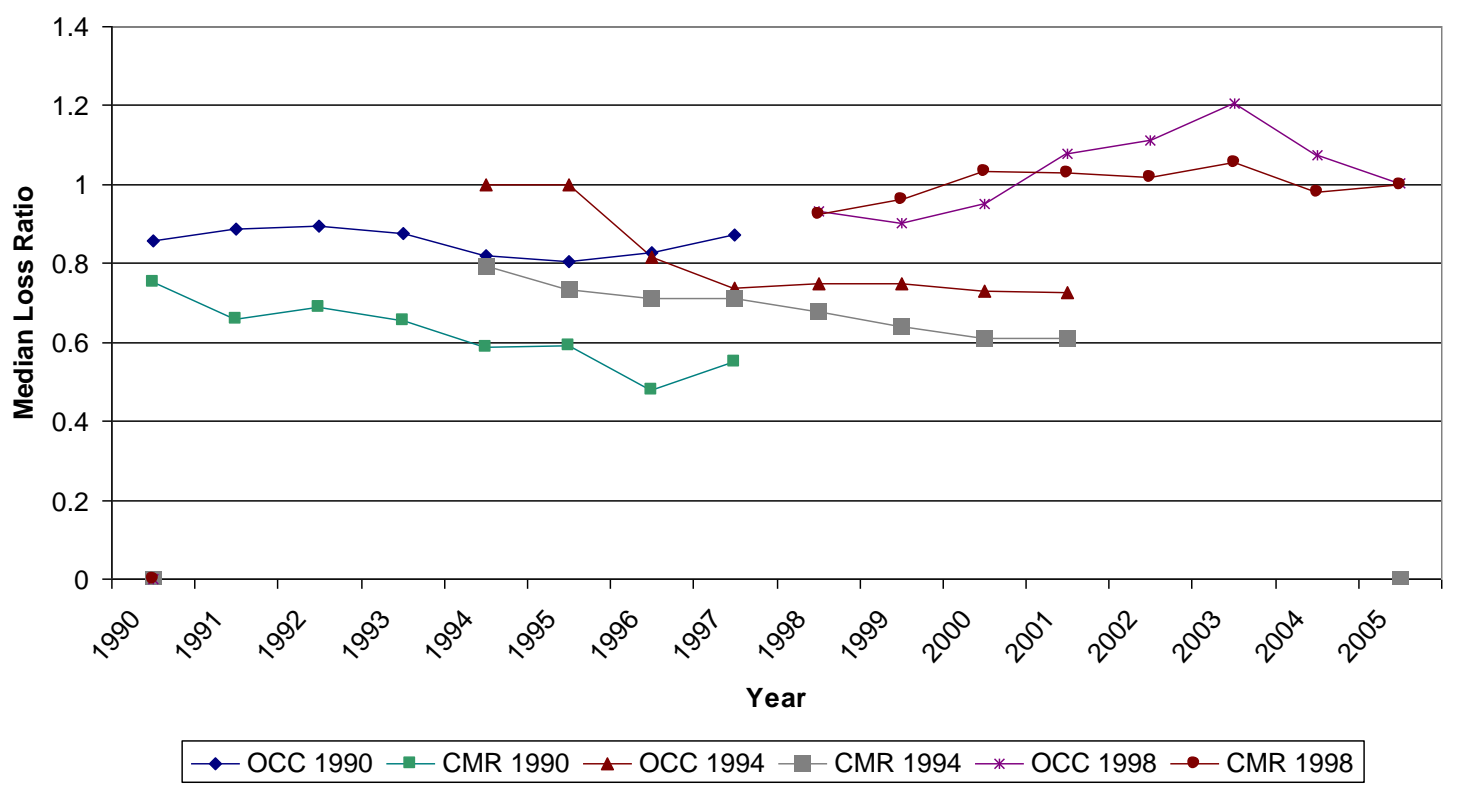

Source: NAIC Annual Data Tapes - Property and Casualty Insurers, Underwriting and Investment Exhibits and Schedule P, Part 2F. The figure includes only firms that reported nonzero premiums and nonzero losses in each initially-reported year (1990,1994, or 1998).

\subsubsection{Reserving errors}

Table 14 displayed previously shows that the median fully developed loss ratio of new insurers selling only OCC policies is 0.730 . The average median loss ratio of all insurers selling OCC contracts over the period 1990-2005 is equal to 0.751. For OCC contracts we see that the fully developed loss ratio of new entrants is marginally lower than the average loss ratio of all insurers over the period, although the difference is not statistically significant. Interestingly, whereas new entrants offering OCC contracts had a lower fully developed loss ratio than established insurers in the market, the opposite occurred for new entrants offering CMR contracts. For insurers writing CMR policies the average median loss ratio during the period 1990-2005 was 0.795 , compared to the fully developed loss ratio of new entrants of 0.815 displayed in Table 14. 
In both cases, the difference between the two loss ratio measures (fully developed for new entrants and the current for all insurers) comes from the fact that the loss ratio is a weighted average of the loss ratio of all the insurers, some having more experience in the line of business than new entrants. Because new entrants in the CMR contract market grossly underestimate incurred losses early in their lives, as we see in Table 14, and that the number of new entrants in the CMR line is quite large (see Table 5), it is therefore normal to see an average loss ratio of insurers writing CMR only contracts to be lower than the average fully developed loss ratio for that line.

Returning our attention to the risk bearing ability of the different organizational forms, our hypothesis was that stock insurance companies were better able to assume catastrophic risks than risk retention groups. A way to measure the risk bearing capacity of different insurers is to compare their variations of their developed losses over the first five years of the contract by type of contract, as depicted in Table 7. Our hypotheses are firstly that stock insurance companies should be better able to assume major variations in reserves so that they should be more aggressive in reserving than risk retention groups (see also Lei and Schmidt, 2006), and secondly that incurred losses associated with OCC policies should be more difficult to predict than incurred losses for CMR policies. Whereas the first hypothesis is related to the management's conscious decision to aggressively manage earnings (if not manipulate earnings), the second hypothesis is related to the uncertainty regarding future losses that come, for instance, from new court awards and changes in legislation, factors that are hardly diversifiable.

To conduct this analysis, we need to construct a statistic that would be correlated with reserving errors of insurers in both the CMR and the OCC contract lines. And because our focus is on reserving errors rather than the sign of these errors and because of the long tail nature of medical malpractice insurance, we need to construct a statistic that would take into account all the absolute size of the errors as well as their cumulated aspect over many years. This reserving error must also be scaled by the insurer's total book of business as the larger insurers' reserving error could be large in value, although it may be small relative to the total size of the enterprise. We shall therefore use the following statistic to measure the volatility of the loss development process of medical malpractice insurance companies over the first five years of development: 


$$
\frac{\left(\text { losses incurred }_{t}-\text { losses incurred }_{t+5}\right)^{2}}{\text { premiums earned }_{t}}
$$

Table 15 presents the results of our analysis by organizational form and by contract type. We see that over the first five years of development, the organizational form that appears to be making the larger reserving errors on average is the stock and mutual insurance company.

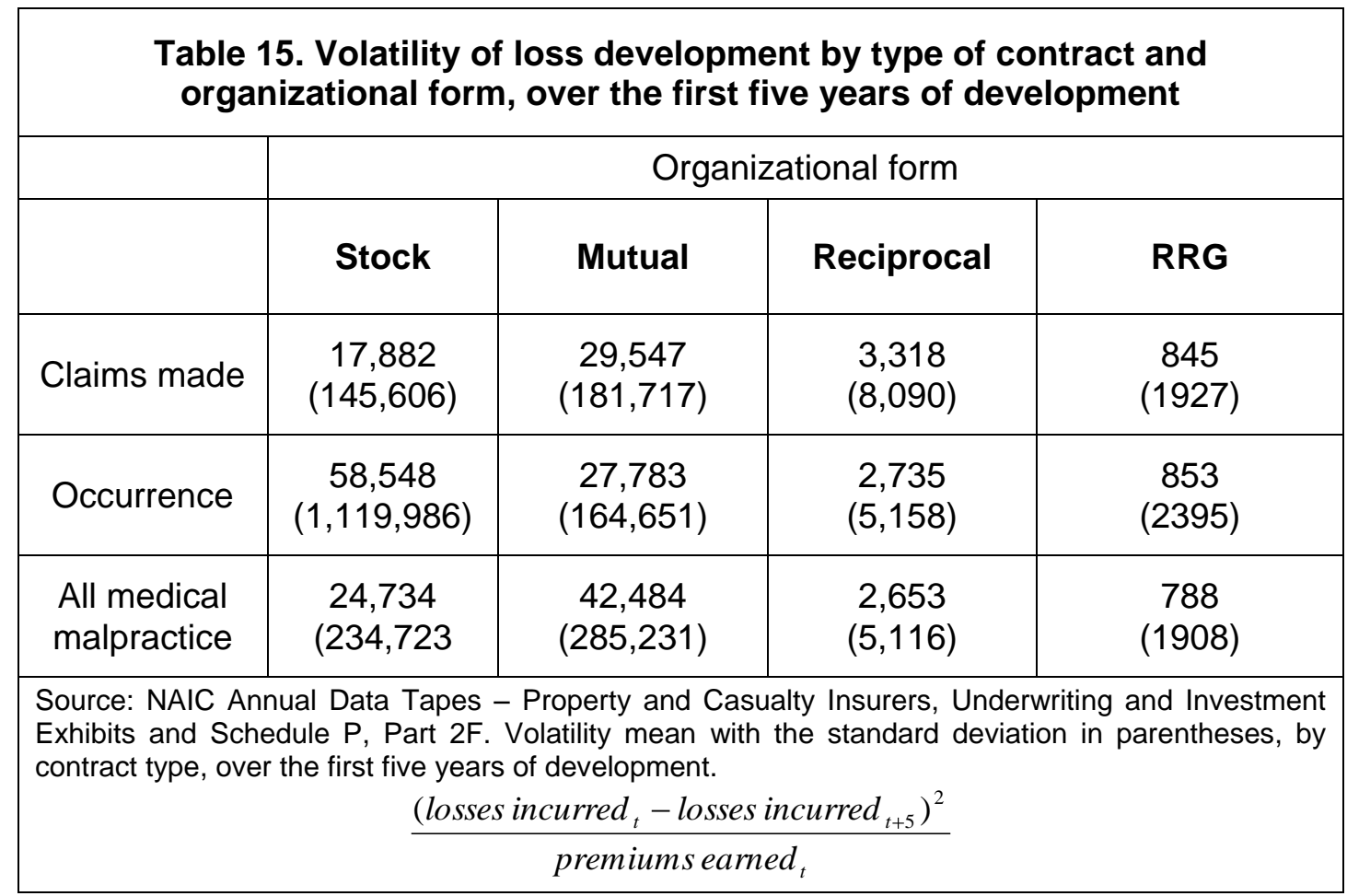

The results in Table 15 are in line with our hypothesis that stock insurers have more leeway in establishing reserves because they are better able to access the capital market when they need. It is also interesting to see that, although mutual insurers and stock insurers have approximately the same average volatility of loss development, the distribution of this volatility is much more dispersed than for mutual insurers, suggesting that stock insurers are more aggressive in the tails. At the other end of the spectrum are the risk retention groups, as we hypothesized being the least able to sustain catastrophic events and therefore in more dire-need to estimate reserves properly.

We also see in Table 15 that CMR contract losses are, on average, easier to predict than OCC contract losses. This result is apparent for all insurers in general, and for three 
of the four organizational insurer types. The only insurer type that appears to have a harder time predicting CMR losses than OCC is the mutual insurer type.

\section{Conclusion}

There is little evidence of the extent to which claims-made and occurrence policies are distributed over time, across states, or across firms. In our review of the literature we noted a general perception that medical malpractice insurers have all switched to claims made policies - abandoning occurrence based policies altogether. ${ }^{10}$ One benefit of our analysis is to provide an up-to-date assessment of the use of these policies. Although claims-made policies may be less risky than occurrence coverage for insurers, since they offer additional flexibility for controlling exposure to long-tail liability losses, it is not clear that this translates into a higher risk-adjusted profitability. We hypothesize that firm and market characteristics jointly explain the use of claims-made versus occurrence policies. While claims-made policies provide an opportunity for insurers to control long term exposures, we suspect that certain types of medical providers demand occurrence coverage due to the nature of the risks they face.

We provided a detailed structure, conduct, and performance analysis of the medical malpractice industry. Focusing on the two distinct types of coverage, we assess changes in the market structure from 1992-2005, where we note a significant movement toward the CMR contract as well as an increase in the participation of RRGs. Our analysis of geographic and line-of-business concentration reveals increased specialization in the medical malpractice line, but for firms continuing to write OCC policies we note an increase in geographic diversification. Finally, our results highlight differences in the loss development, but no robust differences in overall financial performance of insurers who resort to a particular strategy for providing medical malpractice coverage. Further analysis of loss development and other measures of performance may help explain why one particular policy form does not dominate the industry. In a broader context, our research establishes the contribution of an endogenous, strategic decision - the decision to offer CMR or OCC policies - to the performance of the medical malpractice

${ }^{10}$ Recent studies cite Sloan, Bovbjerg and Githens (1991) for a discussion of the issue. Aggregate figures are reported annually by A.M. Best., and are analyzed briefly in Harrington, Danzon and Epstein (2006). 
industry. The potential influence of this decision on malpractice crises will be the subject of future work.

With the ongoing debate about optional federal charters for P\&C as well as life insurance companies, the study of the impact on the availability of insurance and the market conduct of risk retention groups becomes more and more relevant. Debate also rages as to whether risk retention groups, which are currently limited to writing liability insurance coverage, should be allowed to enter the property and other personal lines. The study of risk retention groups combined with the use of the different insurance contracts we presented in this paper (i.e., the claims-made contracts and the occurrence contracts) sheds a light on the topic that had not been seen before. 


\section{References}

Bajtelsmit, Vickie L. and Raja Bousouita (1998). "Market Structure and Performance in Private Passenger Automobile Insurance," Journal of Risk and Insurance, 65 (3): 503-514.

Barker, Drucilla K. (1992). The Effects of Tort Reform on Medical Malpractice Insurance Markets: An Empirical Analysis, Journal of Health Politics, Policy and Law 17: 143.

Berger, Allen (2000), "The Integration of the Financial Services Industry: Where are the Efficiencies?" North American Actuarial Journal, 4.

Berger, Allen N., J. David Cummings and Mary A. Weiss, (1997). "The Coexistence of Multiple Distribution Systems for Financial Services: The Case of PropertyLiability Insurance," Journal of Business, 70: 515-546.

Born, Patricia H. and W. Kip Viscusi (1998). The Distribution of the Insurance Market Effects of Tort Liability Reforms, Brookings Papers on Economic Activity: Microeconomics, 1998.

Boyer M. Martin and Karine Gobert (2007). "Professional Liability Insurance Contracts: Claims Made Versus Occurrence Policies," mimeo HEC Montréal.

Carroll, Anne (1993). "Structure and Performance of the Private Workers' Compensation Market." Journal of Risk and Insurance 60 (2): 185-207.

Choi, Byeongyong Paul and Mary A. Weiss (2005). "An Empirical Evaluation of Market Structure, Efficiency, and Performance in Property-Liability Insurance," Journal of Risk and Insurance, 72 (4): 635-673.

Danzon, Patricia (1984). "The Frequency and Severity of Medical Malpractice Claims." Journal of Law \& Economics 17:115-48.

Danzon, Patricia (1991). "Liability for Medical Malpractice," Journal of Economic Perspectives, 5 (3): 51-69.

Danzon, P.M., A. Epstein, and S. Johnson (2004), "The Crisis in Medical Malpractice Insurance," in R. Litan and R. Herring, eds., Brookings-Wharton Papers on Financial Services 2004, Brookings Institution Press, Washington, D.C

Doherty, Neil A. (1991). "The Design of Insurance Contracts When Liability Rules Are Unstable," Journal of Risk and Insurance, 58 (2): 227-246.

Gaynor, Martin and Deborah Haas-Wilson (1999), "Change, Consolidation, and Competition in Health Care Markets," Journal of Economic Perspectives, 13 (1): 141-164.

General Accounting Office (2005). "Risk Retention Groups: Common Regulatory Standards and Greater Member Protections are Needed." GAO-05-536 (August). 
General Accounting Office (2003). "Medical Malpractice Insurance: Multiple Factors Have Contributed to Increased Premium Rates," GAO-03-702 (June).

General Accounting Office (2003). "Medical Malpractice: Implications of Rising Premiums on Access to Health Care," GAO-03-836 (August).

Grace, Martin F. and J. Tyler Leverty, (2006) "Property-Liability Insurer Reserve ErrorMotive, Manipulation or Mistake?" SSRN Working Paper Series.

Harrington, Scott E., Patricia M. Danzon, and Andrew J. Epstein (2006). " 'Crises' in Medical Malpractice Insurance: Evidence of Excessive Price-Cutting in the Preceding Soft Market," Working Paper.

Joskow, Paul L. (1973) "Cartels, Competition and Regulation in the Property-Liability Insurance Industry." Bell Journal of Economics 4 (2): 375-427.

Kazenski, P., W. Feldhaus, and H. C. Schnieder (1992), "Empirical Evidence for Alternative Loss Development Horizons and the Measurement of Reserve Error," Journal of Risk and Insurance, 59: 668-81.

Kim, Won-Joong, David Mayers and Clifford W. Smith, Jr. (1996) "On the Choice of Insurance Distribution Systems," Journal of Risk and Insurance, 63 (2): 207-227.

Ligon, James A. and Paul D. Thistle. 2005. "The Formation of Mutual Insurers in Markets with Adverse Selection," Journal of Business, 78 (2): 529-556.

Mayers, David and Clifford Smith (1988), "Ownership structure across lines of propertycasualty insurance", Journal of Law and Economics, 31: 351-378.

Petroni, Kathy R., Stephen G. Ryan, and James M. Wahlen (2000). "Discretionary and Non-discretionary Revisoins of Loss Reserves by Property-Casualty Insurers: Differential Implications for Future Profitability, Risk and Market Value," Review of Accounting Studies, 5 (2): 95-125.

Phillips, Richard D., J. David Cummins and Franklin Allen (1998). "Financial Pricing of Insurance in the Multiple-Line Insurance Company," Journal of Risk and Insurance, 65: 597-636.

Posner, James R. (1986). "Trends in Medical Malpractice Insurance, 1970-1985," Law and Contemporary Problems, 49 (2): 37-56.

Seog, H. Sun (1999), "The Coexistence of Distribution Systems When Consumers Are Not Informed," The GENEVA Papers on Risk and Insurance Theory, 24 (2): 173192.

Sloan, Frank A., Randall R. Bovbjerg, and Penny B. Githens (1991). Insuring Medical Malpractice. New York: Oxford University Press.

Studdert, David, Tony Yang, and Michelle Mello (2004). Are Damage Caps Regressive? A Study of Malpractice Verdicts in California, Health Affairs ():54. 
Viscusi, W. Kip and Patricia H. Born (2005). "Damages Caps, Insurability, and the Performance of Medical Malpractice Insurance," Journal of Risk and Insurance, $72(1): 23-43$.

Weiss, Mary (1985), "A Multivariate Analysis of Loss Reserving Estimates in PropertyLiability Insurers," Journal of Risk and Insurance 52 (2): 199-221.

Yoon, Albert (2001). Damage Caps and Civil Litigation: An Empirical Study of Medical Malpractice Litigation in the South. American Law \& Economics Review 3:199227.

Zanjani, George (2007), "Regulation, Capital, and the Evolution of Organizational Form in US Life Insurance," American Economic Review, 97 (3): 973-983.

Zuckerman, S., Randall R. Bovberg, and Frank Sloan (1990). Effects of Tort Reforms and Other Factors on Medical Malpractice Insurance Premiums. Inquiry 27:16782. 


\section{Appendix A}

\begin{tabular}{|c|c|c|c|}
\hline \multicolumn{4}{|c|}{ Table A-1. Joint Underwriting Association (JUAs) Operations in 1996} \\
\hline \multirow[b]{2}{*}{ State } & \multicolumn{2}{|c|}{1996 Operations } & Description \\
\hline & $\begin{array}{l}\text { Direct } \\
\text { Premiums } \\
\text { Written } \\
\text { (\$millions) } \\
\end{array}$ & $\begin{array}{l}\text { JUA Market } \\
\text { Share }\end{array}$ & \\
\hline Florida & $\$ 1.9$ & $0.5 \%$ & JUA writes occurrence policies (2007) \\
\hline Kansas & 0.7 & $1.8 \%$ & \\
\hline Massachusetts & & & $\begin{array}{c}\text { JUA converted to a mutual insurer in } \\
1990 \text { (ProMutual - 80\% market share in } \\
\text { 2004) }\end{array}$ \\
\hline Minnesota & 0.2 & $0.4 \%$ & ? \\
\hline New Hampshire & 5.1 & $20.3 \%$ & $\begin{array}{l}\text { JUA insures about } 10 \% \text { of market in } \\
2004 .\end{array}$ \\
\hline New York & 38.7 & $4.7 \%$ & $\begin{array}{l}\text { Medical Malpractice Insurance Pool, } \\
\text { insured about } 500 \text { physicians in } 2004\end{array}$ \\
\hline North Dakota & & & $\begin{array}{l}\text { The North Dakota Medical malpractice } \\
\text { Insurance Company was established in } \\
2004 \text { - JUA? }\end{array}$ \\
\hline Pennsylvania & 1.2 & $0.6 \%$ & \\
\hline Rhode Island & 5.3 & $20.9 \%$ & $\begin{array}{c}\text { JUA insured about } 700 \text { physicians in } \\
2002 \text { ( } 28 \% \text { of all physicians, } \$ 4 \mathrm{M} \\
\text { premiums) }\end{array}$ \\
\hline South Carolina & 12.3 & $53.4 \%$ & $\begin{array}{l}\text { JUA insured about } 9000 \text { physicians in } \\
\text { 2004; provides coverage on an } \\
\text { occurrence basis. }\end{array}$ \\
\hline Texas & 4.7 & $1.6 \%$ & JUA \\
\hline Wisconsin & 2.7 & $4.0 \%$ & $?$ \\
\hline Wyoming & & & $\begin{array}{l}\text { Medical liability compensation fund } \\
\text { provides physicians with excess } \\
\text { insurance coverage. }\end{array}$ \\
\hline
\end{tabular}

Source: The Status of the Primary and Excess Medical Malpractice Market and the Future Need for the Medical Malpractice Insurance Association, A Report to the Governor and the Legislature by the Superintendent of Insurance, New York, Neil D. Levin, Dec. 1, 1997. 